\title{
Rete Malpighii
}

National Cancer Institute

\section{Source}

National Cancer Institute. Rete Malpighii. NCI Thesaurus. Code C33466.

The deepest layer of the epidermis, which includes both the stratum basale and stratum spinosum as a single layer. 